\title{
Understanding mobile application development and implementation to monitor Posyandu data in Indonesia: a 3-year hybrid action research to build "a bridge" from the community to the national scale
}

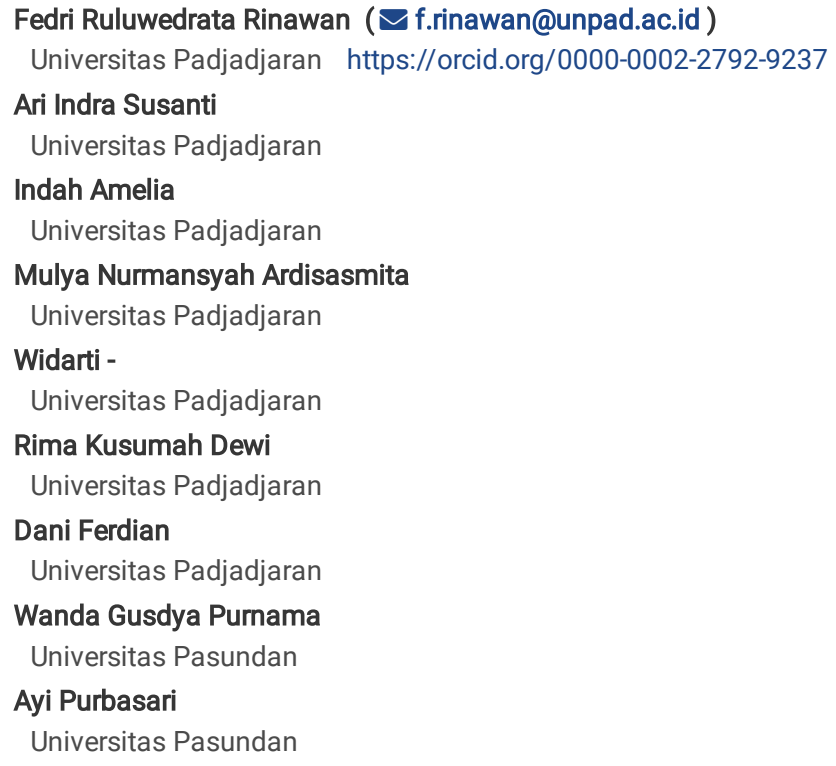




\section{Abstract}

Background. There is a small number of facts available to better understand how mobile health application technology on mother and child health (MCH) is developed. This study is aimed: (a) to explore the process of developing the mobile app in $\mathrm{MCH}$ community-based services in the Indonesian setting/ Posyandu (Pos Pelayanan Terpadu ), (b) to perform feasibility assessment among the community health workers (CHWs), and (c) to see the scalability of the mobile app to the national level in Indonesia.

Methods. A hybrid method in which the action research principles and the mixed method, which comprise qualitative and quantitative methods, were synergistically combined for the end-users. The study was conducted in Pasawahan sub-district, Purwakarta, Indonesia from 2017 to 2019 . Content analysis, coding, and categorizing were carried out using NVivo 12 Pro for the transcribed data. Wilcoxon Test (2018 and 2019) was conducted using STATA 15 Special Edition.

Results. (1) The use of a CHW notebook for data entry in the Posyandu information system book delayed the data reporting process, resulting in the need to develop a mobile app; (2) There are significant differences in CHWs' knowledge ( $p=0.000)$ and skills ( $p=0.0097)$ on training (2018) and Posyandu phases (2019); (3) There have been 964 Posyandu registered to the Posyandu mobile app from almost all provinces in Indonesia.

Conclusions. The 3-year hybrid approach suggests the crucial phases to develop a mobile app in a more user-friendly manner to substitute the use of CHWs old-fashion book use, hence its implementation is promising for national use.

\section{Background}

Mobile health (mHealth) apps in the health sector have been practiced publicly and generate more effective development $(1,2)$. However, its implementation may be complicated due to utility issues among community health workers ( $\mathrm{CHWs}$ )/cadres of mother-child health (MCH) services in the Indonesian setting, known as Posyandu (Pos Pelayanan Terpadu) or integrated service post (2). Action research with a qualitative approach can be implemented to explore the feasibility of an Android-based health application $(3,4)$. Recent systematic reviews suggest little evidence to better understand how the mobile health application tool is designed using qualitative approach to enable the performance of the CHWs in community-based mother and child health services (5-9). In 2019 , some literature reviews pointed out a lack of baseline data prior to the evaluation and experimental studies regarding $\mathrm{CHWs}$ and $\mathrm{mHealth}$ (10).

A qualitative approach in action research is crucial to construct a shred of foundation evidence to design an Android-based application. It is conducted to explore the information on how to adjust and prepare the acceptability rate of the CHWs and mothers to the practice of new intervention where technical problems, such as mobile network overage, internet access, and gadget maintenance may be challenging (11). To adjust the CHWs' work to a new improvement, understanding the principal of the technical scope of ideas in current Posyandu activities is essential. The Posyandu activities consist of 5 categories: registration, height and weight measurement, documentation, education, and healthcare (family planning and immunization). Based on the activities offered, Posyandu is divided into four levels named in order of size, namely: Pratama (five Posyandu activities performed by less than five CHWs in an irregular recurring interval), Madya (activities in Pratama + more than eight activities per year), Purnama (activities in Madya + independent communityfunding with less than 50\% participants), and Mandiri (activities in Purnama + more than $50 \%$ participants). During the registration, a national report form called the Posyandu Information System (PIS) book provided by the Ministry of Home Affairs must be filled by the CHWs and supervised by village midwives. However, a long queue arises as another issue because the CHWs need to find and put the mothers and children's names in the PIS book (12).

Due to time constraints, many CHWs temporarily write the mothers and children's names and data in a book before rewriting them in the monthly and yearly national report. Later, after the end of Posyandu activities, they would enter the recorded data in the PIS book. The time-consuming nature of these data entry and reporting processes becomes a time-management challenge for the $\mathrm{CHWs}$. Therefore, it is necessary to develop a new intervention to support the $\mathrm{CHWs}$ which can be done by exploring their point of view and habits in running the Posyandu. This intervention is essential because the $\mathrm{CHWs}$ have a central role in connecting the community to the national-level through healthcare providers in the Public Health Centers (PHC) or Puskesmas (Pusat Kesehatan Masyarakat) spread across the country (13). Here, the CHWs submit a monthly report to connect the community's condition to the Puskesmas'policy, and the report will serve as a basis for budgeting the community health programs.

Many mobile health technologies (mHealth) are already available in low- and middle-income countries. The use of mHealth can support $\mathrm{CHWs}$ in health care services delivery $(8,11,14)$, community case management $(2,15)$, and health behavior interventions $(7,8)$. There is also a record of the use of mHealth by midwives collaborating with CHWs (16). Some studies also identify mHealth use to help healthcare services for patients and families (6), including for palliative care $(17,18)$, which also highlights its pivotal role $(19)$. A recent literature review proposes that data collection is the main challenge in many community programs and that it should be included in CHW's training by using mHealth (8) so that they can provide more effective support (20). The World Health Organization (WHO) and United Nations Children's Fund (UNICEF) recommend countries to increase the quality of care, monitoring, and assessment using innovative approaches, including maximizing the use of the handheld phone. A systematic manner of data collection, aggregation, analysis, and reporting from the smallest level of administration area (sub-national) to the national one is crucial (21).

Building the CHWs' capacity and supporting their data monitoring and reporting or evaluation within a flexible timeframe is a primary factor for sustaining the community health programs $(8,13)$. Then, identifying the key obstacles in its implementation is a continuing process $(22)$. It is promising to use mHealth because $\mathrm{CHWs}$ can rapidly learn to use it as long as it is adjusted to the local context, such as in terms of the language and user interface (16). In the implementation, the monthly report extracted from the Posyandu Information System (PIS) is required for Puskesmas midwives. The report includes nutrition data of infants, toddlers, pregnant mothers, exclusive breastfeeding mothers in the post-partum period, and couples of reproductive age. 
Many strategies can be applied to motivate mothers to come to the Posyandu. For instance, providing data monitoring service for infants and toddlers' nutrition status, providing immunization status and pregnancy data, providing nutrition counseling by the $\mathrm{CHW}$ to control $\mathrm{MCH}$ programs, and emphasizing the benefits of attending the Posyandu $(12,23)$. Data records and reporting are essential to store the data, which can be a basis of the evidence-based strategies and evaluation of their effectiveness for the Posyandu. It can help the Puskesmas and village office to allocate the necessary budget to improve the existing preventive programs, which will generate feedback for each program's outcomes. In a recent literature review, measuring the effectiveness of $\mathrm{MCH}$ preventive interventions by $\mathrm{CHWs}$ is a critical step for the $\mathrm{MCH}$ programs of a country (20).

Data record and reporting by $\mathrm{CHWs}$ in the Posyandu can be complicated in Indonesia. This is due to the overwhelming number of services provided by $\mathrm{CHWs}$. For instance, $\mathrm{CHWs}$ have to invite mothers and their children to come to the Posyandu and approach those who are not coming. Additionally, CHWs have to communicate with sub-village and religious leaders as a form of community engagement to encourage mothers and children to come to the Posyandu. In the Posyandu, CHWs have to manage the registration, measure the weight and height of the children, record the numbers in a data book, educate mothers and refer them and their children to the village midwife for an immunization appointment, and so on. Because of this, data recording and reporting workload need to be simplified. Critical problem identification should be conducted to be the basis of the initiation and development of solutions. This study is aimed: (a) to explore the process of developing the mobile app, (b) to perform feasibility assessment among the CHWs, and (c) to see the potential scale of the Posyandu mobile app to the national level in the country.

\section{Methods}

Action research consists of a step-by-step development that begins with an assessment to identify initial ideas, implementation, and feedback for improving the ideas. The process is an iterative cycle to support better action or intervention continuously. In this case, the assessment outcomes should meet the needs of the community to prepare the necessary implementation/intervention, which will help the CHWs in making a Posyandu data report. The information is vital to develop a plan to design an intervention starting from the initial blueprint. The intervention design and further actions to deliver the intervention should also be presented to the community for the sake of improvement. The ideas and intervention are also required to be prepared for the advocacy to relevant stakeholders, e.g., government and/or private sectors.

In general, the combination of action research principles and a mixed method research (qualitative and quantitative methods), hereinafter referred to as 'hybrid approach', and is synergistically applied for end-users. The core design comprises an exploratory mixed-method designs, which incorporate more designs into sequences (24). This hybrid approach is deployed in 8 phases: (1) Determining issues by analyzing and understanding users' activities, which refer to a process of exploring their activities at the Posyandu, (2) Making a design prototype blueprint, (3) Evaluating the blueprint with the users through presentation and discussion in which steps 2 and 3 may be repeated should there be any feedback, (4) Designing the prototype, (5) Creating a dynamic design prototype or a dynamic design that is programmed with planned features but still not in the executed form, (6) Evaluating the design with the users to prevent any miscommunication, (7) Testing the executed prototype, and (8) Implementing the final version of the graphical user interface (GUI). Graphical user interface design is an activity to ensure that a good user interface program design is complemented with good quality. It spots interaction between the user and apps using graphical information or visual widgets, such as text boxes and clickable buttons. An approach is needed to bridge the quality and users' needs. Therefore, it can be easier to be accessed by the user (25).

The initial part of the action research was conducted using a qualitative approach because the community insight must be developed after the collection of information. Thus, the GUI can fulfill the needs of the community. In phases 1-2-3-2-4, a qualitative design that was made in 2017 was used for creating, evaluating, and improving a blueprint and then designing a prototype. In 2018, a sequential exploratory mixed-method design and an embedded qualitative approach were performed in phases 4-3-2-4-5 to evaluate and improve the blueprint and the prototype. After the qualitative approach, the knowledge and skills of CHWs in using the app were identified using a quantitative approach during training and it was also embedded with their feedback in the qualitative approach, resulting in a dynamic prototype in 2018. Then, in phases 5-6-5-7-8, the next qualitative and embedded quantitative-qualitative design was tested in 2019 to identify the end users' knowledge and skills (quantitative), including feedback from CHWs on the GUI of the application used during Posyandu activities. Feedback from village midwives who supervised them was also explored (Figure 1).

In practice, the eight spiral phases are explained more as the prototyping stages of the app. We implemented a user-centered design when starting the development from low to high fidelity persona. The stage cycle was iterative, in which we identified the context directly from the users. After that, we explained it in technical terms and the programmer used these as a reference for improvement. When developing a low fidelity persona, we started with a qualitative study to prepare the paperwork to create a blueprint. A Focus Group Discussion (FGD) for the CHWs and mothers were organized to discuss their activities in Posyandu, the importance of mHealth, and the app's main features (box 1 in Figure 1). The first iterative cycle began with a blueprint (box 2 in Figure 1 ) created based on the FGD, and then we went back to them to present it. They gave us some feedback (box 3 in Figure 1), followed by the approval on the improved blueprint (box 2, iterative) before the development of the first high fidelity persona in the Android package (APK) form (box 4, Figure 1).

The first APK was then sent to them and then they installed it as a trial version to use in training. Once they used it, we observed them and organized an FGD regarding the use of the trial version in training (box 3 , iterative). Then, the feedback we received was used to improve the trial version (boxes 2 to 4 , iterative) into a more dynamic solution prototype (box 5 Figure 1). The dynamic prototype was a start for the next iterative cycle. The evaluation was performed using the FGD. This prototype was dynamic in its change and improvement, depending on the iterative cycle process based on the feedback from the users (box 5-65). Then, once the users approved the dynamic prototype, it was then executed and launched in Google Play (GP) (box 7). A study published in 2016 pointed out that internet mobile phone, including Android platform, is used by at least $78 \%$ of people in Indonesia. In 2019, the Indonesia National Broadband Plan targeted a $100 \%$ mobile broadband penetration in urban areas and $52 \%$ in rural areas (26). As of now, the number of people who use Android platform keeps increasing in the country, which is why we selected Android platform that has Google Play as a native app. 
The executed prototype was not the final version, even though we already launched it on GP. It was still an unreleased version and the number of downloads from GP was limited to 6,000 downloads. Before confirming the final GUI (box 8 ) to release the final version, the iterative cycle is crucial for better development. We also conducted the observation and another FGD for CHWs on the use of the app's unreleased version when running the Posyandu. We took into consideration the received feedback as a basis to develop the final GUI of the app (box 8 of figure 1).

For the qualitative research, we established FGDs of 10-14 participants (Table 1), which involved CHWs and mothers in 2017, CHWs in 2018, and CHWs and Midwives from each village in 2019. This method was implemented because these populations engaged more at the Posyandu and were able to use mobile apps. Midwives had a role as Posyandu supervisors in each village. The research was conducted in Pasawahan sub-district, Purwakarta district, West Java province, Indonesia. We interviewed the FGD participants using open questions about the challenges in running the Posyandu to understand their concerns and propose an adequate solution. Then, the input was considered and followed by the users' feedback when the solution was implemented. The qualitative sample was chosen by using a purposive sampling technique according to their activity and ability to use a smartphone. The illustration for this explanation is provided in Figure 2.

To enable the cadres to operate the Posyandu mobile app, an instruction/user guide training was required. The qualitative data were acquired by implementing the FGD with the Posyandu cadres to explore their opinions on the Posyandu mobile app instructions. The FGD was participated by 12 Posyandu cadres representing each village in the Pasawahan sub-district. The information acquired was used to establish a Posyandu mobile app guide needed by the cadres. After the user guide creation process was completed, it was then delivered to the cadres as a reference during the training.

After that, the quantitative data were collected to assess the cadres' knowledge and skills in using the Posyandu mobile app during the training. The knowledge includes account registration management, benefit of the app, pregnant mother identity and physical examination information, toddlers identity and physical examination information, and the Posyandu information system. Meanwhile, the skills include account registration, application login, infants and toddlers data entry, infants and toddlers data display, infants and toddler data search, infants and toddlers examination data entry, infants and toddlers examination data display, pregnant women data entry, pregnant woman data display, pregnant women examination data search, and log out. These are listed on Supplemental Table 5 and 6 . The knowledge assessment was conducted using questionnaires, while the skill assessment was conducted through a quantitative observation by using a checklist. During the observation process, the researchers were assisted by ten selected facilitators, who were the most active and trained cadres.

The facilitators were trained in using the Posyandu mobile app based on the instruction book. Each facilitator should be able to operate the Posyandu mobile app and guide other cadres on how to use the Posyandu mobile app. Each facilitator was provided with an Android mobile phone/tablet and was in charge of 8-10 cadres. The facilitators organized a visit schedule to the cadres they were in charge of. For a month, the Posyandu cadres were guided by the Posyandu mobile app implementation trainer by taking turns using the provided mobile phone/tablet.

The quantitative research sample size was counted based on the objective to test the significance between groups and between two points of time (training time and implementation at Posyandu time). We used per group sample equation from Hulley SB et al. (2007) using a of 0.05 (two-tailed hypothesis), $\beta$ of 0.10 , effect size from previous research of $0,56(27,28)$, resulting in a number of 72 to 86 respondents $(29)$. The treatment group consists of the cadres who meet the inclusion criteria (active cadre) and participated in the Posyandu mobile app training for one day with an instruction book and guided by a trained cadre facilitator. The control group consists of the cadres who meet the inclusion criteria and only participated in the one-day training. The knowledge and skill assessments were conducted one month after the training (2018) and during the implementation of Posyandu (2019).

To see the impact of the local use to scale up to the national level, we released the application on Google Play in December 2018. We analyzed the distribution of registered Posyandu on the mobile app in the country. We used our admin website to download the Excel file comprising all Posyandu that have registered to the Posyandu mobile app and registered the data in one database server. First, we checked the data quality using STATA version 15.1 Special Edition License. Then, to make a distribution map, we used QGIS version 2.6 (open source) shapefile of 34 provinces in Indonesia to map the registered Posyandu until 31 December 2019.

\section{Analysis}

In the qualitative analysis, we coded and categorized the answers of mothers, CHWs, and midwives on end-users activities, the needs of the mobile app, main features of the app (2017); toddlers data input, display, Posyandu mobile app components, benefits of Posyandu, obstacles in using the Posyandu mobile app, learning process, guidebook, its information, cadres expectations and worries (2018); the app development on identity, account, the needs of the website; new menu, and the advantages and disadvantages of the app (2019). We categorized similar answers to a node/code and used the grouping's insight to name the node. We intended to build and understand the critical connection between the needs and recommendations to be used as feedback to the mobile health application design. The analysis used content analysis nodes in NVivo 12 Pro License. The context of the diagram and entity relationship diagram were extracted from the application program maker software. Subsequently, the results were exported and, therefore, could be displayed as a report.

As for the quantitative data analysis, we used STATA version 15.1 Special Edition License to observe the description of respondents' characteristics and to identify the same respondents' knowledge and skills score in 2018 (training) and 2019 (Posyandu activities) using Wilcoxon Test because the data were not normally distributed. We also analyzed the effect by looking at the $\mathrm{Z}$ score (standardized test statistic, produced by STATA) divided by $\sqrt{ } \mathrm{N}(\mathrm{N}=$ number of all respondents) and time difference (training time, 2018 and implementation time, 2019)(30).

\section{Results}

\section{Data Flow Diagram Result in the Database}


Posyandu information system is a system developed to support Posyandu data management and analysis. The collected data were recorded by CHWs, which includes usernames and passwords, mother identities, pregnant mother identities, pregnant mother physical examination results, toddler identity, and toddler physical examination results. This information can also be accessed by CHWs in the monthly report section of the application. The form was already categorized into a monthly and yearly national form. Meanwhile, parents could see the information about their toddlers by performing the following steps: registering using username and password, logging in with the registered credentials, and selecting their children's data that were already recorded by the CHWs. Information that can be accessed by the parents also includes their identity, physical examination results (of a pregnant mother), their children's identity and physical examination results, and mother and child health book. The information is depicted in Figure 3.

\section{Initial Phase Qualitative Research Results (2017)}

The first result consists of the qualitative part of the study, where the input collected from the CHWs and mothers are combined in one table and divided into themes, key insights, and quotes. Table 2 and the details in Supplemental Table 1 show the main problems faced by the CHWs, which is an unorganized yearly data record and report. They stated that the data was hand-written in their notebook. It was easier for them than to write immediately to the big book report, or the Posyandu information system (PIS) book, where one of them confirmed that "the paper notebook can be used immediately." Another CHW also ascertained that "if the data is written directly to the PIS as the mothers come, it will blow my head (since it is) confusing." The CHWs also did not have time to put children's names in an orderly manner, as suggested by one of the CHW. Then, there was also an issue of delay to report to the Puskesmas. This was due to the double burden: data entry to their personal book and report entry to the big book. The CHWs felt that their works were redundant. A worker stated in the FGD that, "(...) we have to write the names to the Posyandu Information System book in an orderly manner." They indicated that they required a solution such as mHealth application to facilitate the data recording and reporting process. The CHWs described it as, "(something) like a tool, but it can be re-accessed, like an archive. Because we need it when Puskesmas requests (a report), sometimes it can be accessed again."

As for the mothers in Supplemental Table 1, the app would help them supervise their toddlers' growth and development. The mothers stated that "(We) need to know our child's development so that we can monitor by ourselves for our child." Moreover, working mothers need to monitor their children's growth while their family members or neighbors were in charge of taking them to the Posyandu. One mother said, "For example, this (child), the child is taken care of by another person (because) the mother is working." They expected not to have to ask the CHWs for a few times to know about their children's growth, because "(it was) just not practical." It was suggested that mothers need Posyandu mHealth application "so that (they) can access it privately (and immediately). Thus, (they) do not have to ask the CHWs continuously."

The activities, including the quoted difficulties above, serve as the input to extend the context in the blueprint of the app. Besides, other inputs such as the registration, connection with children's data, data entry that can also have automatic report output in governmental form, child growth graph, and automatic alert of child growth were also recorded. The main features are depicted in Supplemental Table 1.

Figure 4 illustrates the initial phase of the mobile app for $\mathrm{CHWs}$ /cadres and mothers using touch screen smartphones. In the beginning, the application for the CHWs and mothers differs in the registration menu. Quoted from one of the informants, "First, we click on the Posyandu app, then we register in it, after that we click it once more, then we are connected to our children's data." Mainly, personal data and the name of the nearest Posyandu were needed in the registration before they can log in according to their role as a cadre or a mother.

\section{Middle Phase Qualitative and Quantitative Research Results (2018)}

Table 3 and Supplemental Table 2 illustrate the qualitative theme and key insights that emerged during the training about the use of the Posyandu mHealth application by $\mathrm{CHWs}$ in 2018 . The cadres recommended that the notification feature on the monthly weight data should be automated. Height was measured according to government and WHO guidelines. However, they confirmed that "We do not measure the height monthly but only once every several months." After the cadres enter the required data, they wanted to see the online information on whether the toddler growth chart was increasing or decreasing automatically. Also, they expected the information to be available anytime. To quote, "We want it to be like (...) online reporting, so we do not need to measure the number of decreases." (Supplemental Table 2). By doing so, they expected the app to ease their duties in Posyandu by recording the data and, at the same time, submitting the report to the Puskesmas directly. Nonetheless, when imagining if the app being used in Posyandu, sometimes they still felt confused about some obstacles, "A while ago, some data was successfully stored, but some were unsuccessful." They estimated that the Posyandu situation would be unsupportive when it was crowded, "During the Posyandu working day, it will remain crowded so that the data entry will be done after the end." They also worried about the internet quota availability when they ran out of money.

Considering the pros and cons, the cadres still believed that the app could be a great assistance for them. The learning process played a central role. During the training, they stated that, "We think we can use it because we are used to using and playing with a mobile phone. However, before that, the application should be made available first (on Google Play)." The app was available in the APK form during the training and we had not published it yet on Google Play (GP) at the time. In late 2018, we launched it on GP to make it more widely available and accessible.

During the learning process, they needed more written information in the form of a guidebook. The cadres also coordinated with village officers regarding the solution of any app-related issue. One of the issues was the internet quota, where it was stated that "(...) the Posyandu does not have any budget (to cover it). I asked the villagers about the internet quota fee and they shook their heads." Regardless, it was expected that the cadres could use the app and put them into practice at the Posyandu after the training was ended. They also expressed their interest in using the app, "If using the application if possible, then so be it, (I) cannot wait to use it." More information regarding the feedback can be seen in Supplemental Table 2.

Final Phase Qualitative and Quantitative Research Result (2019) 
Tables 4 and 5 and the detail on supplemental Tables 3 and 4 present the cadres and village midwives FGD results on the Posyandu mobile app development, and advantages and disadvantages analysis of the Posyandu mobile health application, which incorporate the ideas from the cadres and midwives in separate FGDs. When using the app during the Posyandu activities, some corrections would be required, as quoted from one of the informants "Here, the name of my village in this application is wrong." Other feedback recommended inserting a photo in the account information and an alternative password. As a supervisor of cadres in several Posyandus, one of the midwives suggested that "(...) in the future, it would be great if there is an access for the Village Midwife and not only for the cadres," which would bring a positive impact for the next app development. The creation of a website was also discussed for the reporting purpose. The midwives perceived that reporting with a laptop would be easier than with a mobile phone. More feedback is depicted in Table 4/Supplemental Table 3.

We analyze the advantages and disadvantages of the implementation of this application, as indicated in Table 5 and Supplemental Table 4 , from the side of the user, organization, technology, and environment.

Table 5 and Supplemental Table 4 illustrate the resistance of some cadres to change their behavior from paper-based to digital services. In practice, village midwives assisted in supervising and motivating the implementation of the app during the Posyandu activities. Continuous organizational support from the village was vital in 2019 as shown by the research results depicted in these tables, which was also applicable in the previous year. A Standard Operating Procedure (SOP) was essential to be issued by the government, which should address the leadership of the village office, sub-district, Puskesmas, and district health office ( $\mathrm{DHO}$ ). The SOP would strengthen the implementation of the app even though there would be a double work burden at the beginning, which would disappear once they are accustomed to it.

Also, technology is the core part of this implementation. Software and hardware analysis are crucial. In 2018, the app was submitted and launched on Google Play (GP). In 2019, it was available in the GP to be downloaded and operated on an Android mobile phone. The app answered the users' needs as identified in the previous years of action research, such as real-time data entry and report. However, in the region with low network coverage, an offline version was still needed for the next app development. Thus, data submission could be made after the network was available. Some mobile phones found that the unstable network issue persisted, and other mobile phones were not compatible with the app version. It was crucial to continuously improve the version to make it more compatible with all mobile phones.

Evaluation of the cadres' knowledge and skills in the implementation of the Posyandu mobile app during the training (2018) and Posyandu activities (2019) were conducted as ongoing research.

The respondent characteristics are presented in Table 6 . The majority of the respondents were older than 35 years old and most of them received a secondary level of education or Junior High School. In 2018, the respondents consisted of 171 Posyandu cadres. We found a decline of $8.77 \%$ in 2019 . The reason for this was because some respondents were no longer reachable and could not be followed up. Both groups consisted of 15 people. The rest of the respondents could be evaluated up to 79 people in the treatment group and 77 in the control group. Hence, the total number of respondents that could be assessed was 156 people.

The comparison between the knowledge during the training (2018) and the implementation of the Posyandu application (2019) is shown in Table 7.

Based on Table 7, the knowledge and skills of the cadres during the training and Posyandu activities have a significant average score difference equals to the value of $p<0.05$. This score shows that there is a difference in knowledge and skills between the training period and the Posyandu activities period. The effect of knowledge and skills were 0.34 and 0.21 , which is respectively considered small and medium according to Cohen $(30,31)$.

Figure 5 illustrates provincial distribution across 34 provinces in Indonesia until 31 December 2019. As many as 964 Posyandus were registered to the Posyandu mobile app from almost all provinces in Indonesia. The highest number (34.54\%) recorded was in the study area, which was West Java. The rest was in other provinces that shown their interest in registering their Posyandu. After West Java, we identified Belitung, Jakarta, Central Java, and Yogyakarta; sorted from highest to lowest number of registrations. There was no registration from North Kalimantan and Maluku at the time.

\section{Discussion}

Starting qualitative research as a part of the action research is a crucial step to create a basis. Thus, it can develop an intervention that fits with the community problems and adjust their knowledge and skills (32). Some research started formulating an intervention directly based on their initiative without involving the mindset of the targeted community (33). This practice will engender a potential bias when performing the intervention. It can be in the form of a knowledge bias in the sense of a gap between the intervention maker or expert-driven method (which is a top-down maker) and the end user of the intervention $(33,34)$. Creativity in creating mobile health intervention should begin not only through a theory-driven process but also by exploring information from the end user in terms of the targeted community (35). Then, the intervention designer should build details of the intervention design based on the explored information from the users (36). The previous researches compared different top-down and bottom-up applications, where it was revealed that a bottom-up application was more effective in the community (33). Generally, the hybrid approach (Figure 1) consists of a complex mixed-method design that begins with qualitative research, then followed by the combination of sequential and embedded qualitative quantitative designs. The incorporation of the action research into the complex mixed method is in the sense of a cyclical improvement. In one cycle of action research, the results from the qualitative are continued with quantitative design, for example, by quantifying the significance of the implementation effect, which will render it more efficient and useful for the next improvement (action research). This effect can be accompanied by the qualitative research that is embedded with the quantitative research in the view to extend the context of the reasons underlying the quantitative research results. The next cycle can be more complex based on the problem (37). It can be a never-ending cycle for more ultimate improvement. 
The application procedure in 2017 is considered satisfactory if it is established and displayed based on the community feedback because the culturally embedded factors are essential to be explored (38). In the context of this research, the Posyandu cadres and mothers are related in the data flow diagram (DFD), which is the 'kitchen' or back-end of this application. DFD consists of what the cadres and mothers do and what they get from this application. From the previous researches, it is understood that building an application based on the feedback of the application user candidate will juxtapose the user's local context usage perception gap to the designer to support the community's adaptation and acceptance (39). The mobile app technology design can support more benefits in the establishment of strong partnerships between stakeholders to leverage the community capacity and empowerment, e.g., CHWs and mothers $(40,41)$. Empowerment needs a capacity building to maintain the CHWs' and mothers' knowledge and skills to perform screening in the community (42). It is also stated in our research in 2018 about the needs in the learning process (Table 2). The smartphone we used was a touch screen smartphone because it can support the learning process. It corroborates with previous recent literature reviews which point out that it is better to use touch screen mobile phones due to its comfortable use and minimal need for technical support (11). However, our follow-up after the training showed that there was a medium effect on knowledge and a small effect on skills. It differs from the result of another study that employed training intervention to CHWs by using a module in reproductive health and Tuberculosis fields, which demonstrated that there was a large effect. Even though the fields are different, the idea of emphasizing the confidence and satisfaction of $\mathrm{CHWs}$ proposed by the study remains essential and relevant (43). In the future, it is suggested to improve the training by emphasizing such insight as well as considering different measures to reach a larger effect in 6 to 12 months (44). The good impact is that the CHWs will engage more in the intervention and benefit the society and the government (45)

Although, in general, the cadres' knowledge and skills in the Posyandu mobile app implementation have reached expectations, the implementation of a new information system is not easy because there are many influencing factors to be considered. The first factor is the user, where the implementation of a new information system will be successful if each user has a similar performance expectation that the Posyandu mobile app can ease their work burden. Performance expectation is a strong predictor of information system utilization interest (46-48). Another factor is the usage facility, which is defined as when an individual feels certain that using the system does not require any extra effort $(49,50)$.

By using a personal mobile phone, the cadres get more freedom to learn the Posyandu mobile app; thus, there is more time for the cadres to learn to operate it. There is a big opportunity for Indonesian people, including cadres, to learn using their personal mobile phone because from the study published in 2016 , at least $78 \%$ of them were using it. The increase in the cadres' skills is possible because the cadres perform independent learning. Although the cadres only received some information at the beginning and had to learn to operate the application independently, they had similar knowledge and skills with the group of cadres that received specific training. This independent learning is in line with the previous South African research in 2018 where the explorative study demonstrated that the respondent assessment value dramatically increased. However, no intervention was given in the research. The interview result showed that the cadres often gathered and created bigger study groups to learn together (43). In further action research, quantitative research can be performed to objectively evaluate video education that is embedded as part of the mobile app. This research can also be continued by monitoring the steps to identify the development of the cost-effectiveness to strengthen a strong partnership when we do advocacy programs to different stakeholders (51).

In the Indonesian health system, access to screening in Posyandu, which is performed and documented using the Posyandu mobile health application by trained $\mathrm{CHWs}$, can powerfully help the government to improve the data management and, thus, the quality of information. The village midwife, nutrition, and health promotion staffs of Puskesmas have a role in assisting with the activities of the cadres, including to validate the data of the Posyandu before reporting it to the Puskesmas (52). For example, the integration with government programs in the conceptual framework of stunting reduction interventions. There are five pillars of intervention, namely: (1) commitment and vision of leadership; (2) national campaigns and behavior change; (3) convergence of central, regional, and village programs; (4) food and nutrition security; and (5) monitoring and evaluation. In the fifth pillar, the stunting reduction intervention data management system requires an effort to bridge the data management at the village to the district/city level, up to the national level (53). An example of an application available at the national level is the integrated nutrition information system (Integrated Nutrition). The Integrated Nutrition data collection starts from the weighing and measurement data carried out every month at the Posyandu and recorded in the register book. Data entry to the information system falls under the responsibility of the Puskesmas, which can be done at the Posyandu level as a source of growth monitoring data (54). However, we found that the implementation of data entry on the Integrated Nutrition application in the study area is still carried out by Puskesmas staff based on the results of measurements made by health cadres in the Posyandu. This can cause problems, such as delay, in inputting data due to the high workload of the Puskesmas staff. Therefore, an application is needed to solve such issue (9). Our application can bridge the above-mentioned problems through a data input process that is directly carried out by health cadres during the Posyandu's working days. Then, the data can be directly downloaded, verified, and uploaded by the Puskesmas following the Integrated Nutrition application format. This way, the reporting process can run in a timely manner and can be used as a material for the decision-making process related to the efforts to reduce stunting.

The advantages of using mobile health for cadres are supported by our study and recent literature reviews $(6,9-11,51,55,56)$. Studies that have evaluated the program results find some evidence that mobile health application (mHealth) assisted CHWs in enhancing the provided treatment quality, services efficiency, and program monitoring capacity (5). Besides, similar research also reveals that mHealth application is considered as beneficial for $\mathrm{CHWs}$ because it can help them with their duties, support clinical decisions, and send instant data and feedback on the performance (57). Another finding indicates that mobile-based data collection increased the data collection punctuality, decrease the error level, and enhance the data completeness (8).

Nevertheless, our study also found disadvantages, such as user resistance, low organizational support, lack of standard operating procedure, low network coverage punctuality, bugs, hardware challenges, and a non-conducive environment (Table 5). Both advantages and disadvantages can help health promoters to plan continuous improvements in mHealth interventions (58). In general, the CHWs' role in the use of mobile technology is to collect field-based health data, give warnings and reminders on routine Posyandu activities, facilitate health education sessions, and conduct a person-to-person communication with parents. A programmed effort from the cadres can strengthen health services performance (45), which focuses on community-based mother and child health management for primary and secondary health prevention. The sense of doing is in line with another study about community case management on children's illness (15) but different in some settings of the task. The Posyandu's CHWs in our study mainly educate healthy people and refer immunization to the village 
midwives (primary preventions). They also educate at-risk people and perform screening through physical examination (e.g., measuring the weight and height of toddlers), which are recorded in the Posyandu app (secondary preventions). If the cadres found an individual with a suspected illness, such as malnutrition or fever, they will contact the village midwife and then refer the case to the Puskesmas. A leadership and management practice should be emphasized by the local government to support and motivate them to perform these tasks (59) to support a good start of the Posyandu information system through the app and its integration to the national information system. Good leadership, communication, and coordination will engender a robust health information system in Indonesia (60).

\section{Conclusions}

A hybrid approach is an essential and meaningful step in providing the basis of an intervention to fit with the community needs concerning the Posyandu services on data record and reporting. This 3-year hybrid approach with a user-centered design suggests the ideal phases in providing the basis to build a mobile app. The application can be created in a more user-friendly manner, replace the CHWs' old-fashion book use, and build "a bridge" between the community and the national level. In practice, the Posyandu application that we developed is promising to answer the problem of delay in the existing national reporting system. The cadres can contribute to the Posyandu information system by immediately entering the data in real-time. Thus, it can automatically send reports faster to the Puskesmas and district health office.

This research also found that the cadres' knowledge and skills demonstrated a moderate and small improvement, respectively. Yet, both are necessary for the cadres during the performance of Posyandu services in the field. Short dissemination of information followed by continuous monitoring, independent learning, and user-friendly application will result in a satisfactory increase in the cadres' knowledge and skills. The result may be equally satisfying for both the group of cadres that receive training and the one that performs independent learning by using the Posyandu mobile app. For further development, a new educational video in the application on how to use the application is recommended to replace the role of direct or face-to-face dissemination of information.

As the limitation of this study, it did not involve the emphasis on the need to increase the confidence and satisfaction of CHWs when using the Posyandu app. If both aspects are taken into consideration in the future, it may extend the cadres' knowledge and skills more effectively than the result of the current study.

\section{Abbreviations}

CHW: community health worker/cadre; MCH: mother-child health; PHC: Public health center; PIS: Posyandu information system; FGD: focus group discussion; IT: information technology; SOP: standard of procedure; DFD: data flow diagram

\section{Declarations}

\section{Ethics approval and consent to participate}

The ethical committee board of the Faculty of Medicine, Universitas Padjadjaran, and Purwakarta district officials in West Java, Indonesia have approved the proposal of this research. During the research period, we asked for the informants and respondents' informed consent after we explained about the research. The informant (qualitative) and respondent (quantitative) who agreed and signed the consent continued to be part of the research. We also provide explanations regarding the privacy information before the users' approval in the app.

\section{Consent for publication}

Not applicable

\section{Availability of data and materials}

The dataset supporting the conclusions of this article is not publicly available due to confidentiality but is available on a reasonable request.

\section{Competing Interests}

The authors declared no potential conflicts of interest concerning the research, authorship, and/or publication of this article.

\section{Funding}

The authors disclosed receipt of the following financial support for the research and/or publication of this article. This research was funded by Lecturer Competence Internal Grant of Universitas Padjadjaran, Indonesia; PT Astra International Tbk; Indonesia Endowment Fund for Education, abbreviated as LPDP (Lembaga Pengelola Dana Pendidikan); Ministry of Finance; and Kreasi Insani Persada Foundation. The funders had no role in the study design, data collection, analysis, and preparation of the manuscript.

\section{Authors' contributions}

F.R.R., A.I.S., and I.A. performed the process from 2017 study design, data collection, data quality, and manuscript preparation; M.N.A. extracted the DFD design from the server and its explanation in the manuscript; F.R.R, W, and R.K.D. were involved in the study design, data collection, data quality, data analysis of 2018 and 2019, including the manuscript preparation; D.F. analyzed and interpreted "the bridge" between the community and government as a basis to make strong advocacy and partnership, as well as writing them in the manuscript; A.P. and W.G.P. were involved in the preparation of the mobile app 
development including writing the method in the manuscript. They also prepared server data quality, performed back-end analysis, built a website for admin, and interpreted function needed from community and government. All authors have read and approved the manuscript.

\section{Acknowledgments}

The authors acknowledge Puskesmas Pasawahan, Purwakarta district, West Java, Indonesia for facilitating the community work and research in the Posyandu, Purwakarta district health office for permission of conducting the research; Professor Ramdan Panigoro from Department of Biomedical Sciences, Faculty of Medicine, Universitas Padjadjaran Indonesia and Irwan Desrianda, MD for leading and facilitating preliminary basis for the research in 2016 on the community education and research activities performed by students and lecturers; Gilang Abdul Aziz for contributing his expertise on the development of the mobile application. We also acknowledge Injury Working Group, Center for Health System Study and Health Workforce Education Innovation, Faculty of Medicine, Universitas Padjadjaran Indonesia, for the permission of using STATA Special Edition 15.1 license.

\section{Authors' information}

${ }^{1}$ Department of Public Health, Faculty of Medicine, Universitas Padjadjaran, Jl. Eyckman No. 38, Bandung 40161, West Java, Indonesia. ${ }^{2}$ Center for Health System Study and Health Workforce Education Innovation, Faculty of Medicine, Universitas Padjadjaran, Jl. Eyckman No. 38, Bandung 40161, West Java, Indonesia. ${ }^{3}$ Mother and Child Health Division, Department of Public Health, Faculty of Medicine, Universitas Padjadjaran, Jl. Eyckman No. 38, Bandung 40161, West Java, Indonesia. ${ }^{4}$ Biostatistics and Epidemiology Division, Department of Public Health, Faculty of Medicine, Universitas Padjadjaran, JI. Eyckman No. 38, Bandung 40161, West Java, Indonesia. ${ }^{5}$ Midwifery Master Study Program, Faculty of Medicine, Universitas Padjadjaran, JI. Eyckman No. 38, Bandung 40161, West Java, Indonesia. ${ }^{6}$ Puskesmas Sungai Durian, Jl. MT Haryono Gg. Wiyata 2, Kelurahan Kapuas Kanan Hulu, Kecamatan Sintang, Kab. Sintang, 78614. ${ }^{7}$ Makassar Regional General Hospital, Jl. Perintis Kemerdekaan No.KM.14, Daya, Kec. Biringkanaya, Kota Makassar, Sulawesi Selatan 90243 , ${ }^{8}$ Informatics Engineering Study Program, Faculty of Engineering, Universitas Pasundan, Jl. Dr. Setiabudi No.193, Bandung 40153, West Java, Indonesia.

\section{References}

1. Fonda SJ, Kedziora RJ, Vigersky RA, Bursell SE. Combining iGoogle and personal health records to create a prototype personal health application for diabetes self-management. Telemed J E Health. 2010;16(4):480-9.

2. Källander K, Tibenderana KJ, Akpogheneta JO, Strachan LD, Hill Z, ten Asbroek AAH, et al. Mobile Health (mHealth) Approaches and lessons for increased performance and retention of community health workers in low- and middle-income countries: a review. J Med Internet Res. 2013;15(1):e17.

3. Rifkin SB. Examining the links between community participation and health outcomes: a review of the literature. Health Policy and Planning. 2014;29(suppl_2):ii98-ii106.

4. Walji N. Leadership: An action research approach. Ai \& Society. 2009;23(1):69-84.

5. Braun R, Catalani C, Wimbush J, Israelski D. Community Health Workers and Mobile Technology: A Systematic Review of the Literature. PLOS ONE. 2013;8(6):e65772.

6. Silva BMC, Rodrigues JJPC, de la Torre Díez I, López-Coronado M, Saleem K. Mobile-health: A review of current state in 2015. Journal of Biomedical Informatics. 2015;56:265-72.

7. Payne HE, Lister C, West JH, Bernhardt JM. Behavioral Functionality of Mobile Apps in Health Interventions: A Systematic Review of the Literature. JMIR mHealth and uHealth. 2015;3(1):e20.

8. Agarwal S, Perry HB, Long LA, Labrique AB. Evidence on feasibility and effective use of mHealth strategies by frontline health workers in developing countries: systematic review. Tropical medicine \& international health : TM \& IH. 2015;20(8):1003-14.

9. Feroz A, Jabeen R, Saleem S. Using mobile phones to improve community health workers performance in low-and-middle-income countries. BMC Public Health. 2020;20(1):49.

10. Early J, Gonzalez C, Gordon-Dseagu V, Robles-Calderon L. Use of Mobile Health (mHealth) Technologies and Interventions Among Community Health Workers Globally: A Scoping Review. Health Promotion Practice. 2019;20(6):805-17.

11. Amoakoh-Coleman M, Borgstein AB-J, Sondaal SFV, Grobbee DE, Miltenburg AS, Verwijs M, et al. Effectiveness of mHealth Interventions Targeting Health Care Workers to Improve Pregnancy Outcomes in Low- and Middle-Income Countries: A Systematic Review. Journal of Medical Internet Research. 2016;18(8):e226.

12. Nazri C, Yamazaki C, Kameo S, Herawati DMD, Sekarwana N, Raksanagara A, et al. Factors influencing mother's participation in Posyandu for improving nutritional status of children under-five in Aceh Utara district, Aceh province, Indonesia. BMC Public Health. 2016;16(1):69.

13. Pallas SW, Minhas D, Pérez-Escamilla R, Taylor L, Curry L, Bradley EH. Community Health Workers in Low-and Middle-Income Countries: What Do We Know About Scaling Up and Sustainability? American Journal of Public Health. 2013;103(7):e74-e82.

14. Sonderman KA, Nkurunziza T, Kateera F, Gruendl M, Koch R, Gaju E, et al. Using mobile health technology and community health workers to identify and refer caesarean-related surgical site infections in rural Rwanda: a randomised controlled trial protocol. BMJ open. 2018;8(5):e022214.

15. O'Connor Y, Hardy V, Heavin C, Gallagher J, O’Donoghue J, editors. Supporting LIFE: Mobile health application for classifying, treating and monitoring disease outbreaks of sick children in developing countries. International conference on design science research in information systems; 2015: Springer.

16. Little A, Medhanyie A, Yebyo H, Spigt M, Dinant G-J, Blanco R. Meeting community health worker needs for maternal health care service delivery using appropriate mobile technologies in Ethiopia. PloS one. 2013;8(10):e77563-e. 
17. Allsop MJ, Powell RA, Namisango E. The state of mHealth development and use by palliative care services in sub-Saharan Africa: a systematic review of the literature. BMJ Supportive \&amp; Palliative Care. 2018;8(2):155-63.

18. Namisango E, Ntege C, Luyirika EBK, Kiyange F, Allsop MJ. Strengthening pharmaceutical systems for palliative care services in resource limited settings: piloting a mHealth application across a rural and urban setting in Uganda. BMC Palliative Care. 2016;15(1):20.

19. Arisanti N, Sasongko EPS, Pandia V, Hilmanto D. Implementation of palliative care for patients with terminal diseases from the viewpoint of healthcare personnel. BMC Research Notes. 2019;12(1):217.

20. Gilmore B, McAuliffe E. Effectiveness of community health workers delivering preventive interventions for maternal and child health in low- and middleincome countries: a systematic review. BMC Public Health. 2013;13(1):847.

21. WHO, UNICEF. WHO/UNICEF joint statement: integrated community case management (iCCM). 2012.

22. Labrique AB, Vasudevan L, Kochi E, Fabricant R, Mehl G. mHealth innovations as health system strengthening tools: 12 common applications and a visual framework. Global Health: Science and Practice. 2013;1(2):160-71.

23. Anwar F, Khomsan A, Sukandar D, Riyadi H, Mudjajanto ES. High participation in the Posyandu nutrition program improved children nutritional status. Nutr Res Pract. 2010;4(3):208-14.

24. Creswell JW, Creswell JD. Research design: Qualitative, quantitative, and mixed methods approaches. Fifth ed: Sage publications; 2018.

25. Banerjee I, Nguyen B, Garousi V, Memon A. Graphical user interface (GUI) testing: Systematic mapping and repository. Information and Software Technology. 2013;55(10):1679-94.

26. Puspitasari L, Ishii K. Digital divides and mobile Internet in Indonesia: Impact of smartphones. Telematics and Informatics. 2016;33(2):472-83.

27. Park K-G, Han S, Kaid LL. Does social networking service usage mediate the association between smartphone usage and social capital? New Media \& Society. 2013;15(7):1077-93.

28. Bisallah Cl, Rampal L, Lye M-S, Sidik SM, Ibrahim N, lliyasu Z, et al. Effectiveness of health education intervention in improving knowledge, attitude, and practices regarding Tuberculosis among HIV patients in General Hospital Minna, Nigeria-A randomized control trial. PloS one. 2018;13(2).

29. Hulley SB, et al. Designing Clinical Research. 3rd ed: Lippincott Williams \& Wilkins; 2007.

30. Field A. Discovering statistics using IBM SPSS statistics: North American edition: Sage; 2017.

31. Pallant J. SPSS Survival Guide Manual 6th edition. Two Penn Plaza. New York, NY: McGraw Hill Education; 2016.

32. Brydon-Miller M, Greenwood D, Maguire P. Why action research? Action research. 2003;1(1):9-28.

33. Musselwhite C, Freeman S, Marston HR. Transcendent Technology and Mobile eHealth. Mobile e-Health: Springer; 2017. p. $299-306$.

34. de Beurs D, van Bruinessen I, Noordman J, Friele R, van Dulmen S. Active involvement of end users when developing web-based mental health interventions. Frontiers in psychiatry. 2017;8:72.

35. Walsh DM, Moran K, Cornelissen V, Buys R, Claes J, Zampognaro P, et al. The development and codesign of the PATHway intervention: a theory-driven eHealth platform for the self-management of cardiovascular disease. Translational behavioral medicine. 2018.

36. Still B, Crane K. Fundamentals of user-centered design: A practical approach: CRC Press; 2017.

37. Palinkas LA, Mendon SJ, Hamilton AB. Innovations in mixed methods evaluations. Annual review of public health. 2019;40:423-42.

38. Mangwi Ayiasi R, Atuyambe LM, Kiguli J, Orach CG, Kolsteren P, Criel B. Use of mobile phone consultations during home visits by Community Health Workers for maternal and newborn care: community experiences from Masindi and Kiryandongo districts, Uganda. BMC Public Health. 2015;15(1):560.

39. Aranda-Jan CB, Mohutsiwa-Dibe N, Loukanova S. Systematic review on what works, what does not work and why of implementation of mobile health (mHealth) projects in Africa. BMC Public Health. 2014;14(1):188.

40. Kouadio IK, Ghazi HF, Maimaiti N, Rahimi A, Aljunid SM. Potential of mobile technology in meeting the public health needs in developing countries. BMC Public Health. 2012;12(2):A13.

41. Puri S, Fernandez S, Puranik A, Anand D, Gaidhane A, Quazi Syed Z, et al. Policy content and stakeholder network analysis for infant and young child feeding in India. BMC Public Health. 2017;17(2):461.

42. Basu P, Mahajan M, Patira N, Prasad S, Mogri S, Muwonge R, et al. A pilot study to evaluate home-based screening for the common non-communicable diseases by a dedicated cadre of community health workers in a rural setting in India. BMC Public Health. 2019;19(1):14.

43. Plowright A, Taylor C, Davies D, Sartori J, Hundt GL, Lilford RJ. Formative evaluation of a training intervention for community health workers in South Africa: A before and after study. PloS one. 2018;13(9).

44. Armaou M, Araviaki E, Musikanski L. eHealth and mHealth Interventions for Ethnic Minority and Historically Underserved Populations in Developed Countries: an Umbrella Review. International Journal of Community Well-Being. 2019:1-29.

45. Sabo S, Flores M, Wennerstrom A, Bell ML, Verdugo L, Carvajal S, et al. Community Health Workers Promote Civic Engagement and Organizational Capacity to Impact Policy. Journal of Community Health. 2017;42(6):1197-203.

46. Olushola T, Abiola J. The efficacy of technology acceptance model: A review of applicable theoretical models in information technology researches. Journal of Research in Business and Management. 2017;4(11):70-83.

47. Magsamen-Conrad K, Upadhyaya S, Joa CY, Dowd J. Bridging the divide: Using UTAUT to predict multigenerational tablet adoption practices. Computers in human behavior. 2015;50:186-96.

48. Dwivedi YK, Rana NP, Jeyaraj A, Clement M, Williams MD. Re-examining the unified theory of acceptance and use of technology (UTAUT): Towards a revised theoretical model. Information Systems Frontiers. 2019;21(3):719-34.

Page $10 / 22$ 
49. Marangunić N, Granić A. Technology acceptance model: a literature review from 1986 to 2013. Universal Access in the Information Society. 2015;14(1):8195.

50. Lai P. The literature review of technology adoption models and theories for the novelty technology. JISTEM-Journal of Information Systems and Technology Management. 2017;14(1):21-38.

51. Lee SH, Nurmatov UB, Nwaru BI, Mukherjee M, Grant L, Pagliari C. Effectiveness of mHealth interventions for maternal, newborn and child health in lowand middle-income countries: Systematic review and meta-analysis. Journal of Global Health. 2016;6(1):010401.

52. Holipah, Maharani A, Kuroda Y. Determinants of immunization status among 12- to 23-month-old children in Indonesia (2008-2013): a multilevel analysis. BMC Public Health. 2018;18(1):288.

53. Ministry of National Development Planning. Guideline on stunting integrated intervention in districts/cities. 2018. http://tnp2k.go.id/filemanager/files/Rakornis\%202018/Pedoman\%20Pelaksanaan\%20Intervensi\%20Penurunan\%20Stunting\%20Terintegrasi\%20Di\%20Ka Accessed on 24 May 2020.

54. Ministry of Health. Guideline on integrated nutrition information system. 2019. http://sigiziterpadu.gizi.kemkes.go.id/ Accessed 11 May 2020.

55. Smisha A, B. PH, Lesley-Anne L, B. LA. Evidence on feasibility and effective use of mHealth strategies by frontline health workers in developing countries: systematic review. Tropical Medicine \& International Health. 2015;20(8):1003-14.

56. Chib A, van Velthoven MH, Car J. mHealth Adoption in Low-Resource Environments: A Review of the Use of Mobile Healthcare in Developing Countries. Journal of Health Communication. 2015;20(1):4-34.

57. Kallander K, Tibenderana JK, Akpogheneta OJ, Strachan DL, Hill Z, ten Asbroek AH, et al. Mobile health (mHealth) approaches and lessons for increased performance and retention of community health workers in low- and middle-income countries: a review. J Med Internet Res. $2013 ; 15(1): e 17$.

58. lyengar S. Chapter 12 - Mobile health (mHealth). In: Gogia S, editor. Fundamentals of Telemedicine and Telehealth: Academic Press; 2020. p. $277-94$.

59. Costello A, Peterson S, Rasanathan K, Daelmans B, Bahl R. Where's the leadership? Future commitments of Unicef and WHO for global child health. BMJ. 2018;362:k3219.

60. Faridah L, Rinawan FR, Fauziah N, Mayasari W, Dwiartama A, Watanabe K. Evaluation of Health Information System (HIS) in The Surveillance of Dengue in Indonesia: Lessons from Case in Bandung, West Java. International Journal of Environmental Research and Public Health. 2020;17(5):1795.

\section{Tables}

Table 1. Number of Participants in Each Phase of the Study

\begin{tabular}{|l|c|c|c|c|c|}
\hline \multirow{2}{*}{ Participants } & \multicolumn{5}{|c|}{ Number of participants in each phase year } \\
\cline { 2 - 6 } & 2017 & \multicolumn{2}{|c|}{2018} & \multicolumn{2}{|c|}{2019} \\
\cline { 2 - 6 } & Qualitative & Qualitative & Quantitative & Qualitative & Quantitative \\
\hline CHWs & 13 & 12 & 171 & 10 & 156 \\
\hline Mothers & 14 & & & & \\
\hline Midwives & & & & 11 & \\
\hline
\end{tabular}

Table 2. End-User Activities, the Needs of Mobile App, and Main Features 


\begin{tabular}{|c|c|c|}
\hline No & Theme & Key insight \\
\hline 1 & End-user activities & \\
\hline & a. CHWs' activities & $\begin{array}{l}\text { i. The direct use of CHWs' notebooks for } \mathrm{MCH} \text { service } \\
\text { ii. Delay in rewriting to the Posyandu information system (PIS) book } \\
\text { iii. PIS book is extremely hard to implement }\end{array}$ \\
\hline & a. Mothers' activities & $\begin{array}{l}\text { i. Mothers who work will ask others to bring their children to the Posyandu: } \\
\text { ii. } \\
\begin{array}{l}\text { 1. babysitter } \\
\text { 2. grandmother } \\
\text { 3. neighbor }\end{array}\end{array}$ \\
\hline 2 & The needs of mobile app & \\
\hline & a. $\mathrm{CHW}$ & $\begin{array}{l}\text { i. Monitoring infants, toddlers, and mothers } \\
\text { ii. CHWs need a mobile app to report to Puskesmas }\end{array}$ \\
\hline & b. Mother & i. Mothers need a mobile app to monitor their toddlers \\
\hline 3 & Main features & $\begin{array}{l}\text { i. Login } \\
\text { ii. 12-Month Reporting Format } \\
\text { iii. Similar to the reporting form used in Puskesmas } \\
\text { iv. Infant data input to be automatic data when the app is re-opened } \\
\text { v. Child growth graph } \\
\text { vi. Automatic alert of child growth }\end{array}$ \\
\hline
\end{tabular}

Table 3. The use of Posyandu mHealth Application by $\mathrm{CHW}$ 


\begin{tabular}{|c|c|c|}
\hline No & Theme & Key Insight \\
\hline 1 & Toddler Data Input & $\begin{array}{l}\text { a. Toddler body weight measurement } \\
\text { b. Toddler body height measurement time } \\
\text { c. Toddler body height measurement according to WHO }\end{array}$ \\
\hline 2 & Toddler Data Display & $\begin{array}{l}\text { a. Toddler data can be accessed anytime } \\
\text { b. Toddler measurement result display } \\
\text { c. Parents can access toddler data }\end{array}$ \\
\hline 3 & Posyandu Mobile App Components & $\begin{array}{l}\text { a. Posyandu mobile app menu } \\
\text { b. Online report }\end{array}$ \\
\hline 4 & Benefits of Posyandu Mobile app & $\begin{array}{l}\text { a. Posyandu reporting and recording is easier than the big book report } \\
\text { b. Facilitate cadres' duties in Posyandu }\end{array}$ \\
\hline 5 & Obstacles in using Posyandu mobile app & $\begin{array}{l}\text { a. Confused/need to adapt } \\
\text { b. Unsupportive Posyandu situation }\end{array}$ \\
\hline 6 & Learning process & $\begin{array}{l}\text { a. Cadres' knowledge of the Posyandu mobile app } \\
\text { b. Cadres' skills on the use of the Posyandu mobile app } \\
\text { c. Cadres need more training about the app }\end{array}$ \\
\hline 7 & Posyandu mobile app guidebook & $\begin{array}{l}\text { a. Significance of Posyandu mobile app guidebook } \\
\text { b. Guidebook format } \\
\text { c. Guidebook size } \\
\text { d. Guidebook writing style } \\
\text { e. Images in the guidebook }\end{array}$ \\
\hline 8 & Information in the guidebook & $\begin{array}{l}\text { a. Instruction } \\
\text { b. How to register an account/log in } \\
\text { c. How to input toddler data } \\
\text { d. How to input pregnant mother data }\end{array}$ \\
\hline 9 & Cadres' expectation & $\begin{array}{l}\text { a. Tablet/mobile phone provision } \\
\text { b. Use of application in Posyandu }\end{array}$ \\
\hline 10 & Cadres' worries & a. Internet quota availability \\
\hline
\end{tabular}

Table 4. Cadres and Village Midwives FGD Result on Posyandu Mobile App Development

\begin{tabular}{|l|l|l|}
\hline No. & \multicolumn{1}{|c|}{ Theme } & \multicolumn{1}{|c|}{ Key Insight } \\
\hline 1. & Identity & Village name correction in the editing menu \\
\hline 2. & Account & Account owner photo \\
\hline & & Alternative password \\
\hline & & Individual account for village midwife \\
\hline 3. & Website & Web creation \\
\hline 4. & New menu & Pregnancy age automatic calculation \\
\hline
\end{tabular}

Table 5. Advantages and Disadvantages Analysis of Posyandu Mobile Health Application 


\begin{tabular}{|c|c|c|c|}
\hline No & Analysis Result & Advantages & Disadvantages \\
\hline \multirow[t]{5}{*}{1} & User & & \\
\hline & a. Receipt & Cadres' approval of the application & \\
\hline & b. Problem Solving & $\begin{array}{l}\text { Problem solution by the cadre when facing a } \\
\text { difficulty }\end{array}$ & \\
\hline & c. Skill & $\begin{array}{l}\text { Cadre's skill in operating the Posyandu Mobile } \\
\text { app }\end{array}$ & \\
\hline & d. Resistance & & $\begin{array}{l}\text { Time-consuming because there is a reluctance on the part of some cadres } \\
\text { to change into digital system-based services }\end{array}$ \\
\hline \multirow[t]{4}{*}{2} & Organization & & \\
\hline & a. Policy & $\begin{array}{l}\text { Presence of a village midwife leadership as } \\
\text { the direct supervisor of Posyandu activities }\end{array}$ & \\
\hline & $\begin{array}{l}\text { b. Organizational } \\
\text { Support }\end{array}$ & & $\begin{array}{l}\text { Cadres' facility in the implementation of the Posyandu mobile app is still } \\
\text { necessary }\end{array}$ \\
\hline & $\begin{array}{l}\text { C. Standard Operating } \\
\text { Procedure (SOP) }\end{array}$ & $\begin{array}{l}\text { Positive response in the advocacy of the } \\
\text { government }\end{array}$ & $\begin{array}{l}\text { Double work burden of manual and digital tasks because there is no SOP } \\
\text { that regulates the implementation of Posyandu mobile app }\end{array}$ \\
\hline \multirow[t]{12}{*}{3} & Technology & & \\
\hline & a. Application/Software & & \\
\hline & i. Accuracy & Appropriate and correct use of the application & \\
\hline & 1. Facility & $\begin{array}{l}\text { User-friendliness of the application when } \\
\text { being operated the cadre }\end{array}$ & \\
\hline & 1. Availability & $\begin{array}{l}\text { Availability of the application in Google Play to } \\
\text { be used or operated }\end{array}$ & \\
\hline & 1. Relevance & $\begin{array}{l}\text { Conformity of the application menu with the } \\
\text { needs of the cadres or as planned by the } \\
\text { government }\end{array}$ & \\
\hline & 1. Punctuality & $\begin{array}{l}\text { Real-time condition of the application to } \\
\text { display the information or examination result }\end{array}$ & $\begin{array}{l}\text { In the region with low network coverage, an offline version of the } \\
\text { application is needed for data entry, which will be submitted after the } \\
\text { network appears }\end{array}$ \\
\hline & 1. Challenge & & Application bugs need to be fixed \\
\hline & b. Hardware & & \\
\hline & i. Network & & Unstable network for some providers/carriers \\
\hline & 1. Mobile Phone & & Some versions of Android are not compatible with the application \\
\hline & 1. Quota & & Some cadres do not have internet quota \\
\hline 4. & Environment & & $\begin{array}{l}\text { The situation that is not conducive (queueing issue) during Posyandu's } \\
\text { business time }\end{array}$ \\
\hline
\end{tabular}

Table 6. Respondent Characteristics in Pasawahan Sub-District, Purwakarta District in 2018 and 2019 


\begin{tabular}{lcccc}
\hline \multirow{2}{*}{ Characteristics } & \multicolumn{2}{c}{2018} & \multicolumn{2}{c}{2019} \\
\cline { 2 - 5 } & $\begin{array}{c}\text { Treatment } \\
(\mathrm{n}=86)\end{array}$ & $\begin{array}{c}\text { Control } \\
(\mathrm{n}=85)\end{array}$ & $\begin{array}{c}\text { Treatment } \\
(\mathrm{n}=79)\end{array}$ & $\begin{array}{c}\text { Control } \\
(\mathrm{n}=77)\end{array}$ \\
\hline Age (year old $)$ & 18 & 22 & 16 & 19 \\
$26-35$ & 32 & 33 & 31 & 33 \\
$36-45$ & 36 & 30 & 32 & 25 \\
$46-55$ & & & & \\
Education & 24 & 31 & 21 & 26 \\
Elementary School & 32 & 33 & 30 & 30 \\
Junior High School & 30 & 21 & 28 & 21 \\
$\quad$ Senior High School & 30 & & &
\end{tabular}

Table 7. Comparison of Knowledge and Skills during Training and Posyandu Activities

\begin{tabular}{|c|c|c|c|c|c|c|c|}
\hline \multirow[t]{2}{*}{ Variable } & \multirow[t]{2}{*}{ Occasion } & \multicolumn{4}{|c|}{ Value } & \multirow[b]{2}{*}{ Effect } & *Wilcoxon signed-rank test \\
\hline & & Min & $\operatorname{Max}$ & Mean & P-Value & & \multirow{5}{*}{ Figures } \\
\hline \multirow[t]{2}{*}{ Knowledge } & Training & 84 & 100 & 94.69 & $* 0.0000$ & 0.34 & \\
\hline & Posyandu Activity & 76 & 100 & 91.91 & & & \\
\hline \multirow[t]{2}{*}{ Skill } & Training & 7.69 & 100 & 85.63 & $* 0.0097$ & 0.21 & \\
\hline & Posyandu Activity & 27.63 & 100 & 93.05 & & & \\
\hline
\end{tabular}

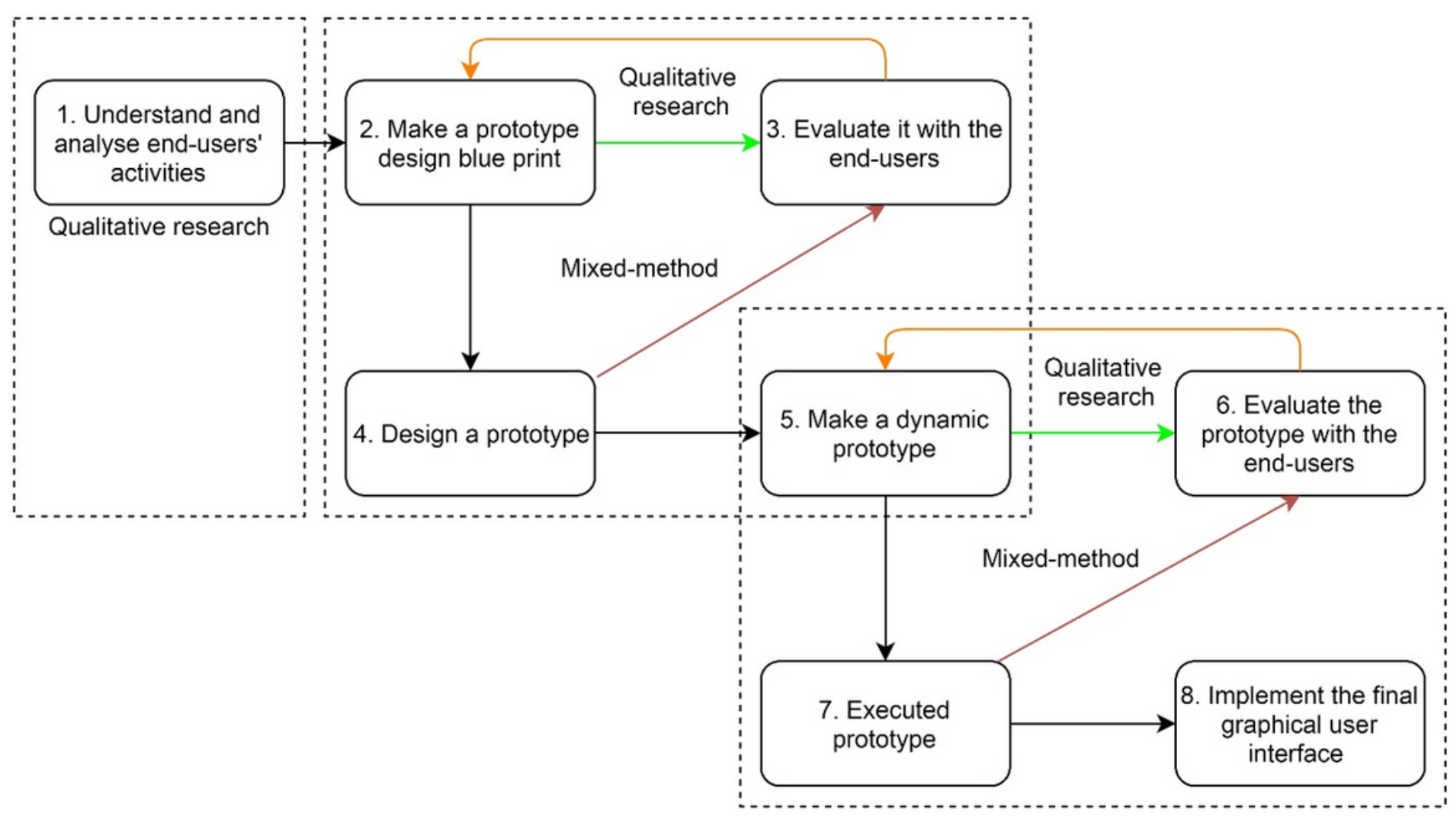

\section{Figure 1}

Hybrid approach (action research principal and mixed-method research design) to develop the Posyandu application 


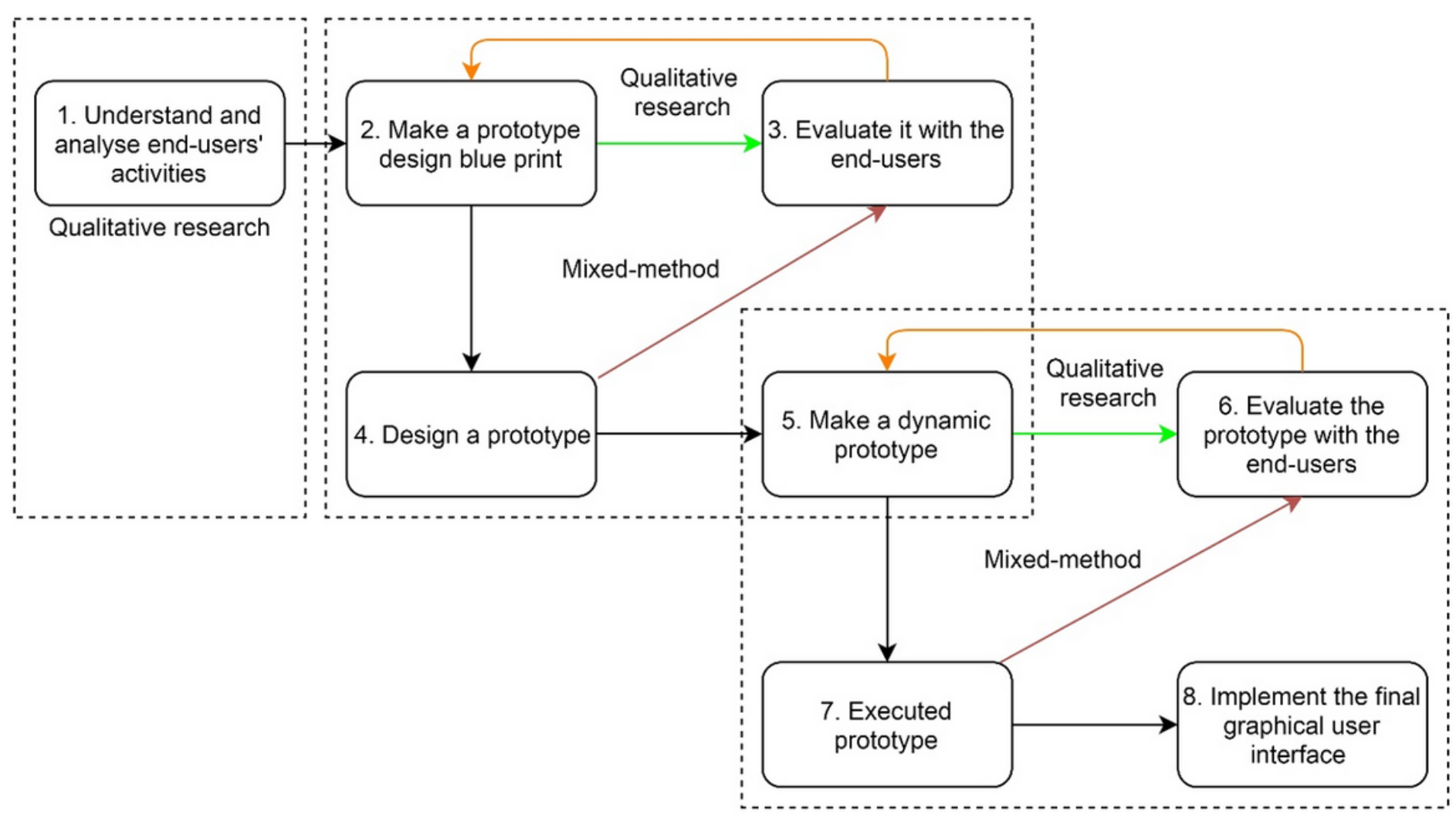

Figure 1

Hybrid approach (action research principal and mixed-method research design) to develop the Posyandu application 


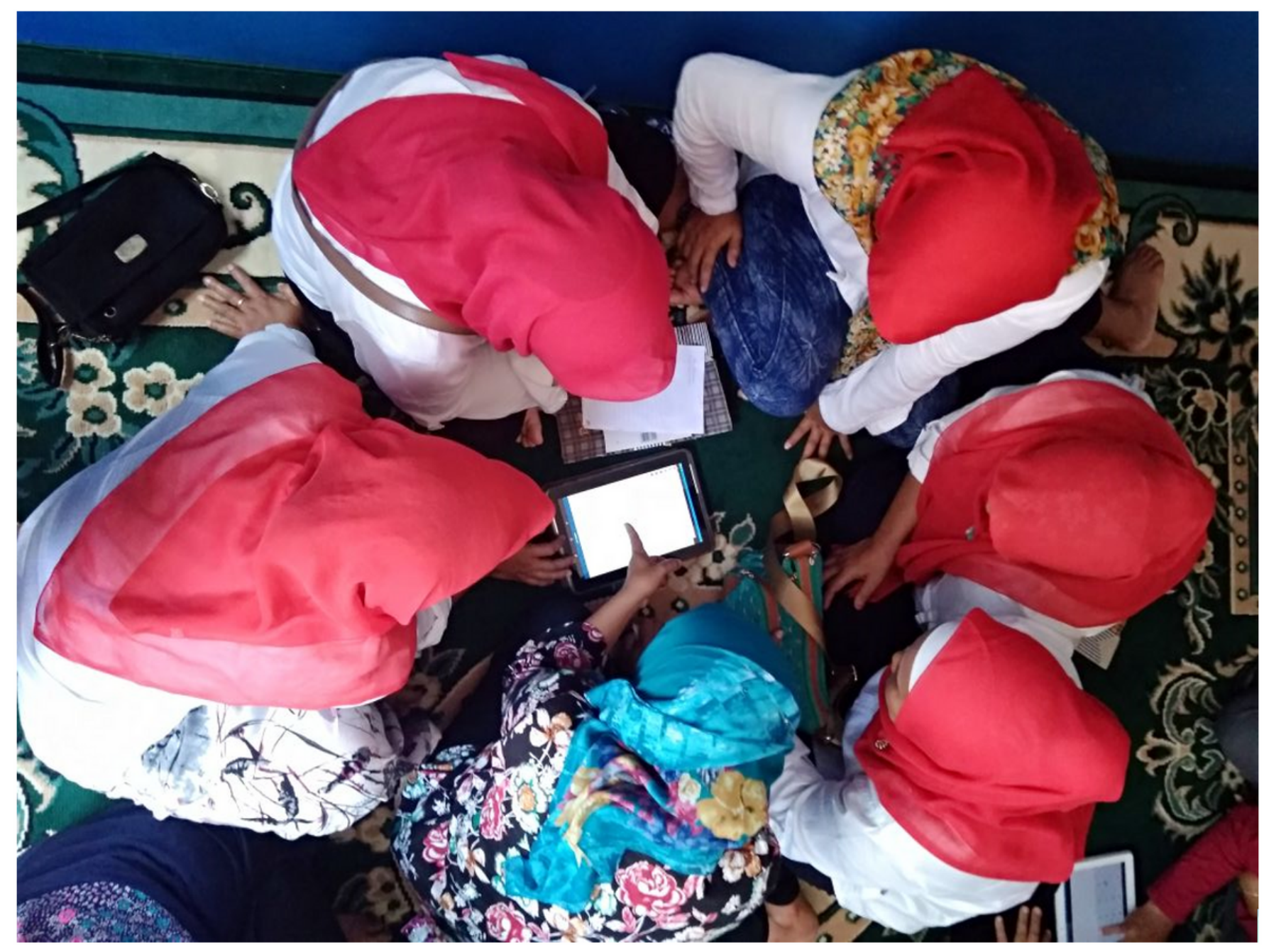

Figure 2

The process of Focus Group Discussion for a dynamic evaluation and execution of the Posyandu application 


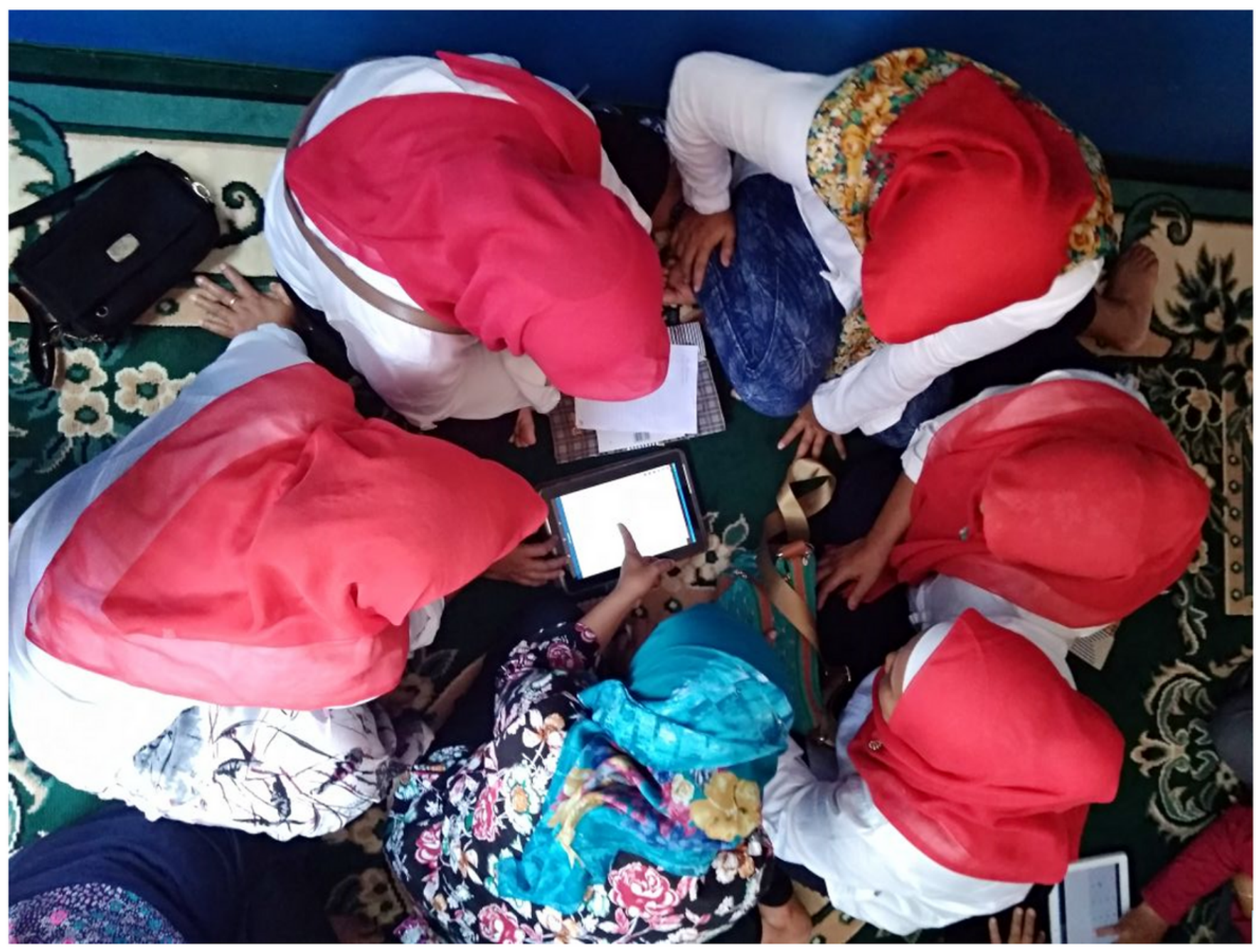

Figure 2

The process of Focus Group Discussion for a dynamic evaluation and execution of the Posyandu application

1. Mother of under-five identity information

2. Pregnant mother identity information

3. Pregnant mother physical examination information

4. Under-five identity information

5. Under-five physical examination information

6. Report form to Primary healthcare centre

7. Mother and child health book
1. Mother of under-five identity information

2. Pregnant mother identity information

3. Pregnant mother physical examination information

4. Under-five identity information

5. Under-five physical examination information

6. Mother and child health book

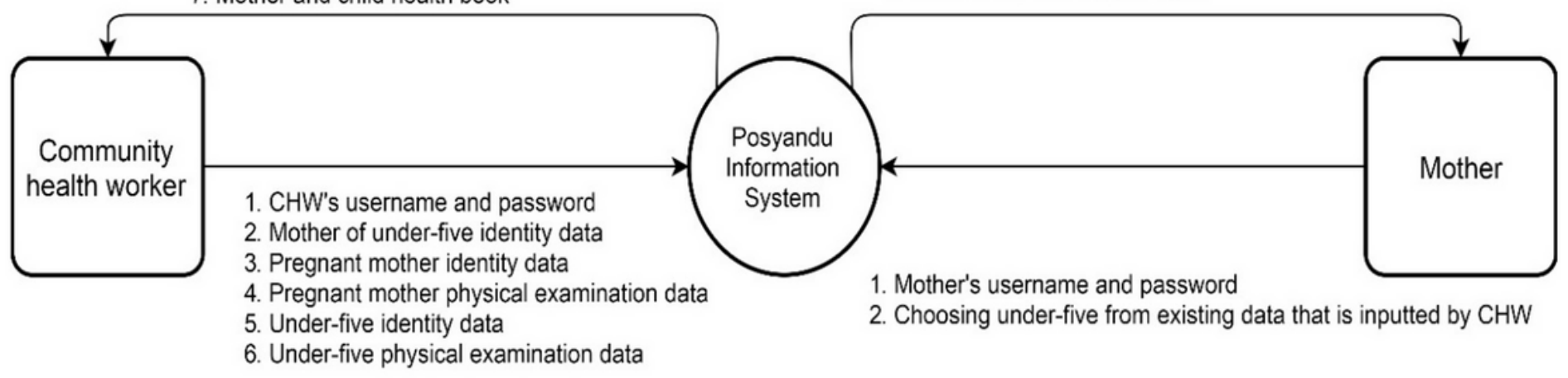

Figure 3

Data flow diagram of mobile health application design in the Posyandu Information System 


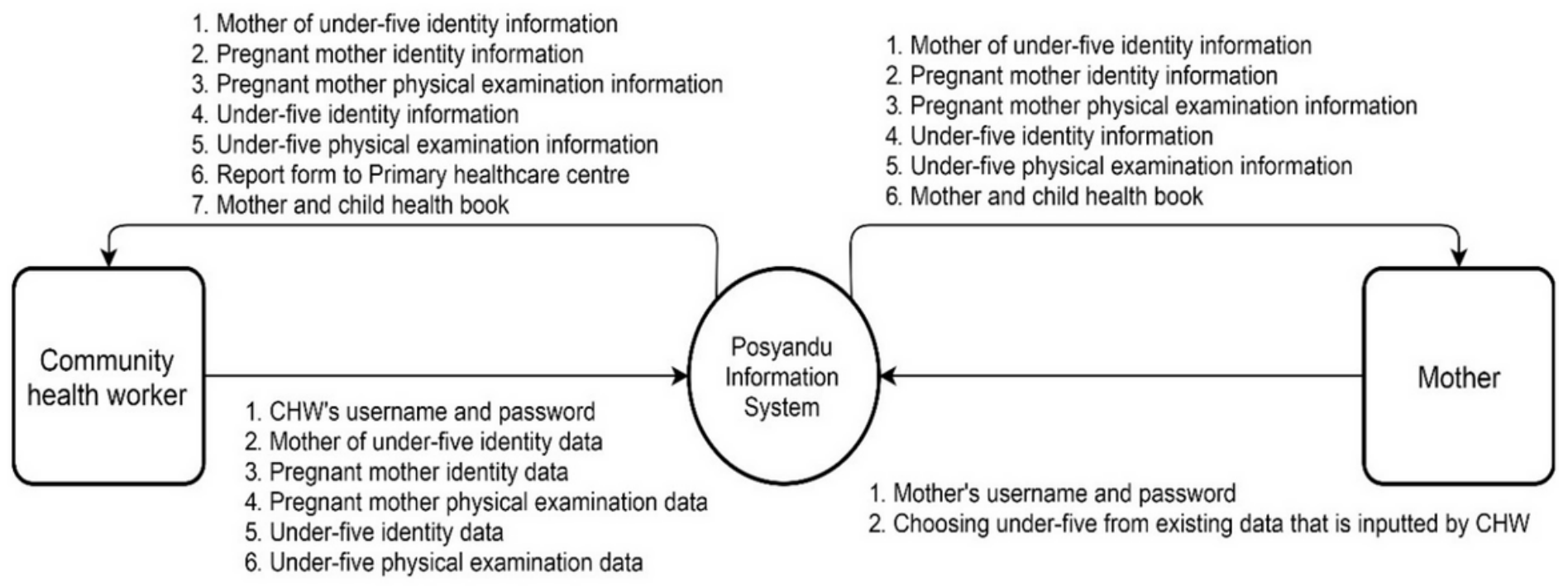

Figure 3

Data flow diagram of mobile health application design in the Posyandu Information System
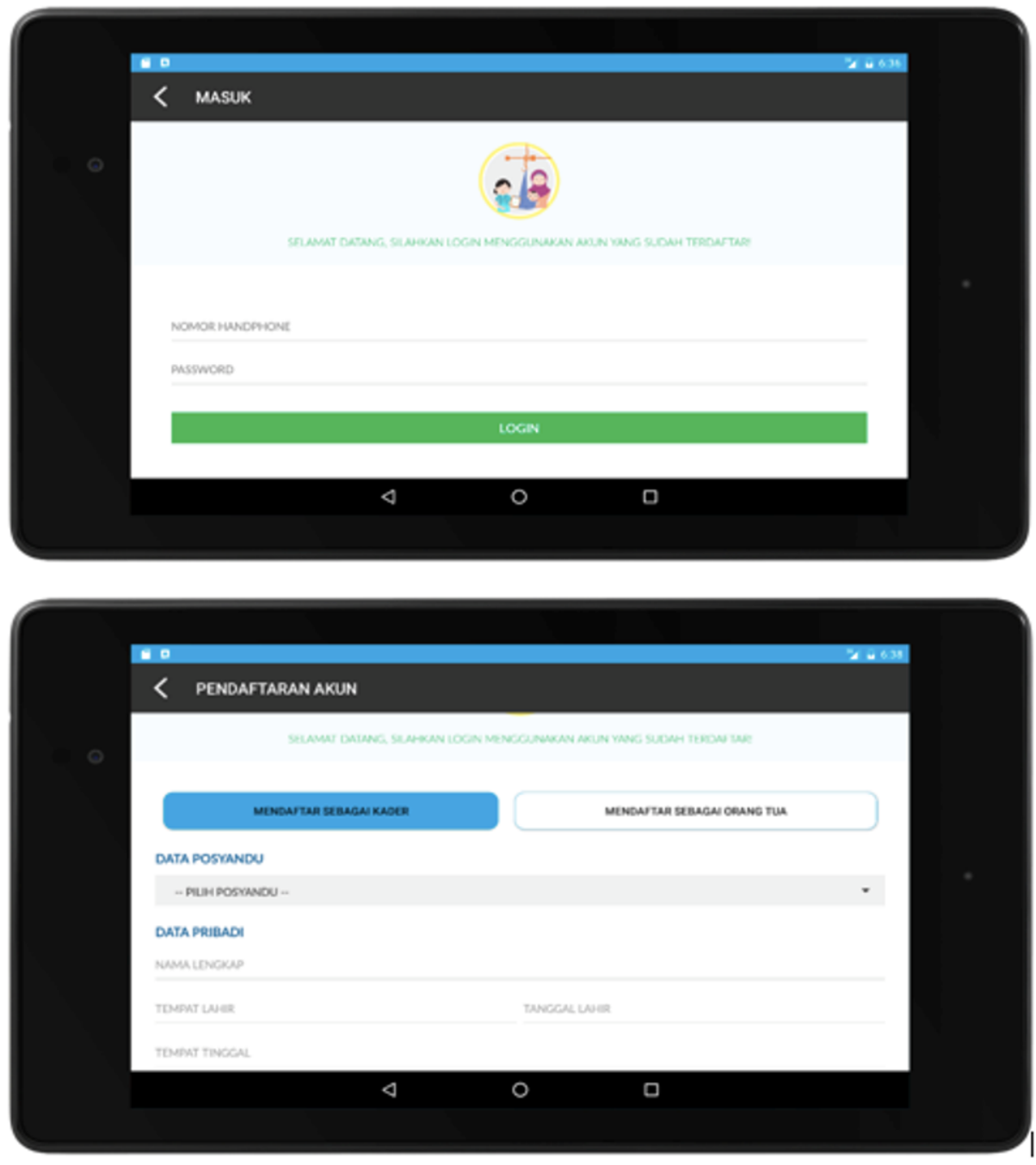

Figure 4

Log in page and registration page of the Posyandu mobile health application 

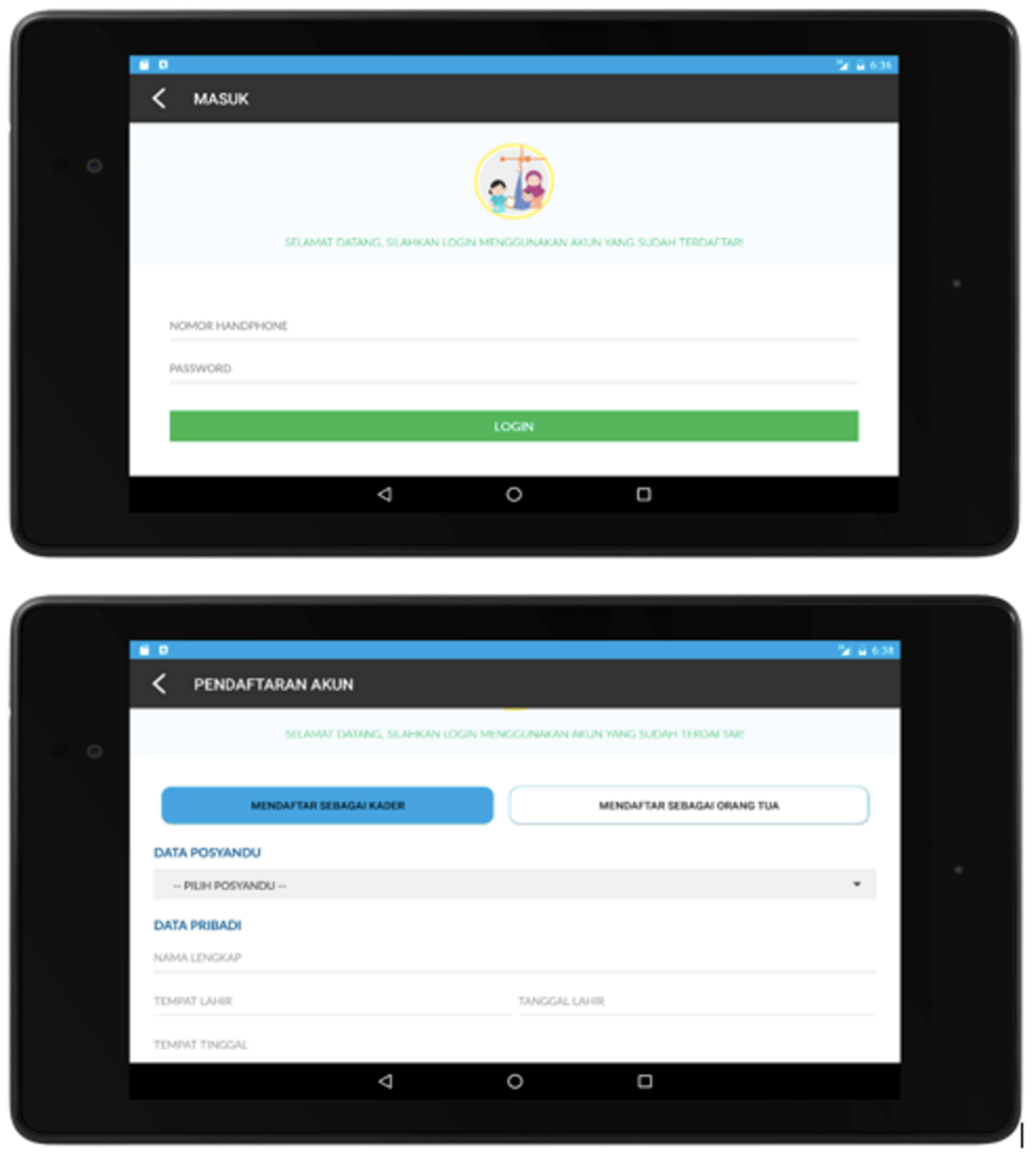

Figure 4

Log in page and registration page of the Posyandu mobile health application 


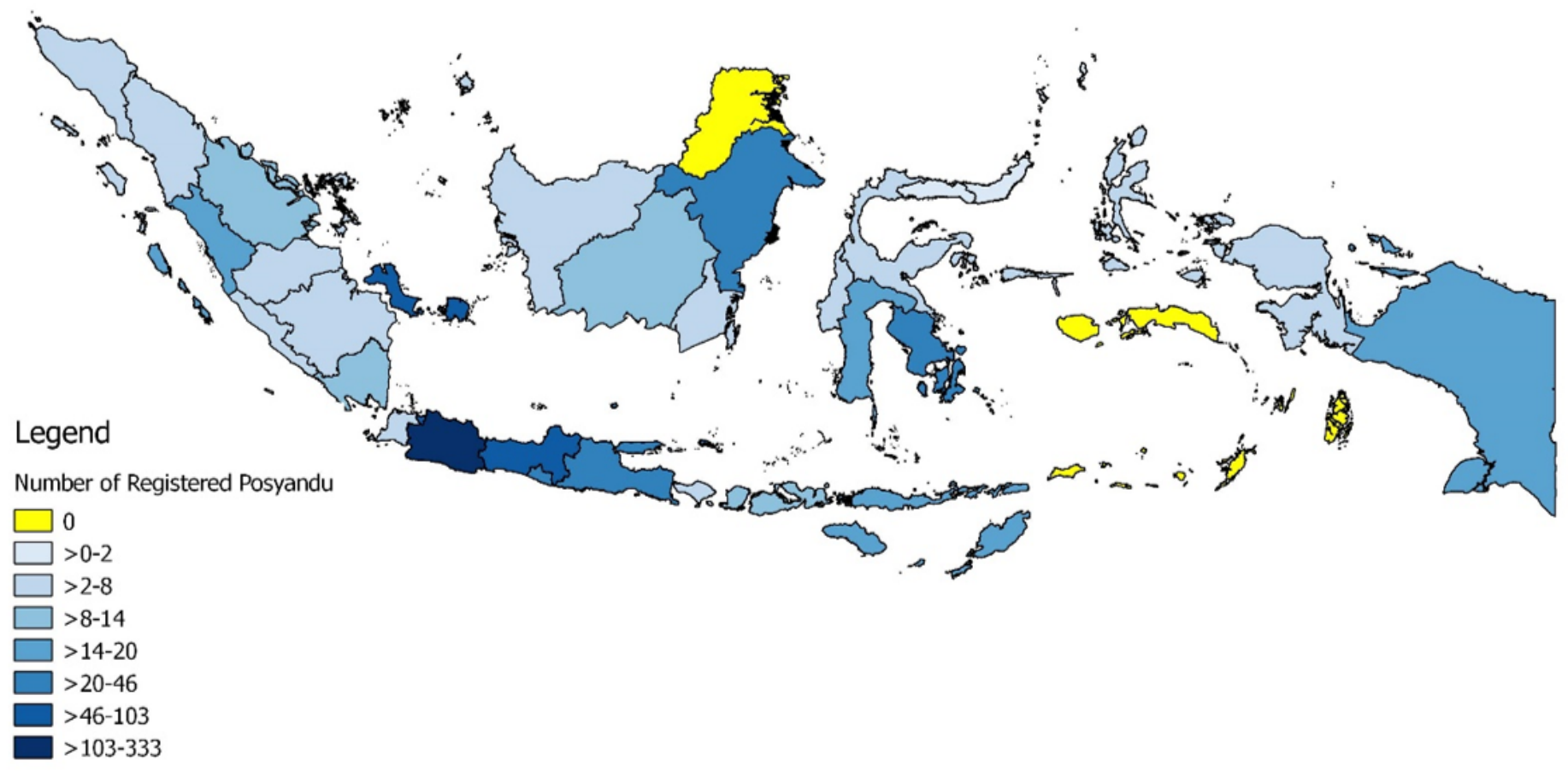

Figure 5

Distribution of registered Posyandu in the mobile app in Indonesia until 31 December 2019

2019

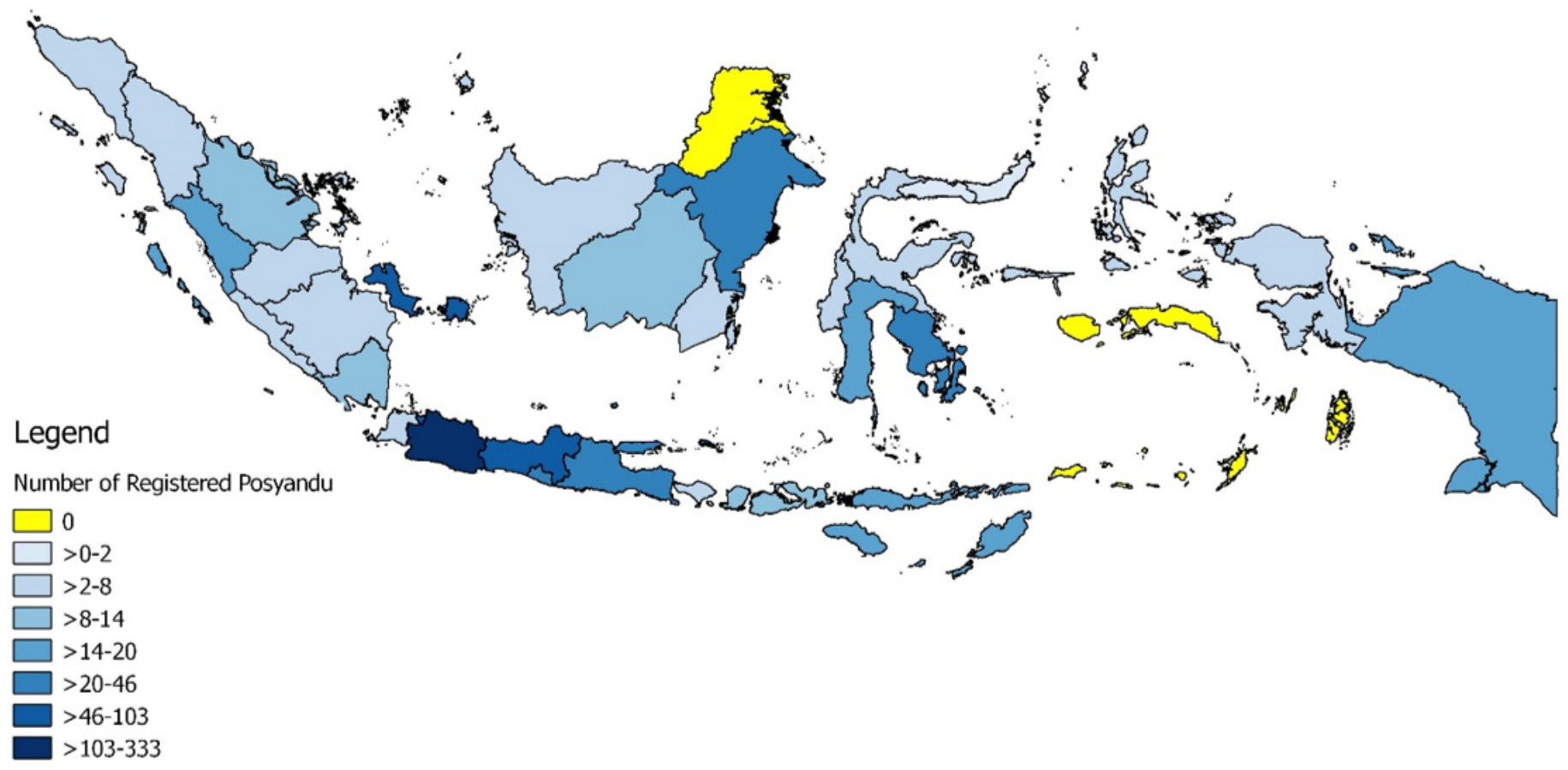

Figure 5

Distribution of registered Posyandu in the mobile app in Indonesia until 31 December 2019 


\section{Supplementary Files}

This is a list of supplementary files associated with this preprint. Click to download.

- SupplementalMaterialrev2.docx

- SupplementalMaterialrev2.docx 